\title{
Knowledge, Attitudes and Use of E-Cigarettes
}

\author{
Zrinka Puharić, ${ }^{1,2}$, Valentina Smola', Mirna Žulec ${ }^{1}$, \\ Stjepan Grabovac ${ }^{1,3}$, Filip Puharić ${ }^{4}$, Nina Petričević ${ }^{5}$ \\ ${ }^{1}$ University of Applied Sciences Bjelovar, Bjelovar, Croatia, ${ }^{2}$ Faculty of Dental Medicine \\ and Health, Josip Juraj Strossmayer University of Osijek, Osijek, Croatia, ${ }^{3}$ General hospital \\ Bjelovar, Bjelovar, Croatia, ${ }^{4}$ Medical Faculty, University of Rijeka, Rijeka, Croatia, ${ }^{5}$ Public \\ Health Institute „Andrija Štampar“, Zagreb, Croatia
}

\begin{abstract}
Aim: Investigate knowledge, attitudes and use of e-cigarettes among Croatian population with validated online questionnaire. Methods: Study included 531 subjects who volunteered to participate and was done using online anonymous questionnaire in 2017; the link to questionnaire was on social media on the University of Applied Sciences Official web site. To limit duplicate responses, one response per IP address was permitted. Specially designed questionnaire using internationally validated surveys: „The young people in Scotland schools omnibus 2014: questions on e-cigarettes", "Monitoring the future-National survey results on drug results" and The European commission-Special Eurobarometer Report-Attitudes of Europeans towards tobacco and electronic cigarettes. Results: There were 379 (71.4\%) women and 152 (28.6\%) men in the study. Almost all (97.9\%) participants in have heard of e-cigarettes. The prevalence rate of current use of e-cigarettes is (5.8\%) of all respondents-9.2\% men and 4.5\% women. Men know more about e-cigarettes $\left(\chi^{2}=8.573, s s=2, p=0.014\right)$, and use it more often than women $\left(\chi^{2}=4.406, s s=1, p=0.036\right)$. The largest number of users are in the age group of 18-30 years, and the largest number of respondents who are seeing advertisements for e-cigarettes see them in social media. People with lower education have tried e-cigarettes more than people with higher level of education $\left(\chi^{2}=9.750, s s=3, p=0.020\right)$. Cigarettes smokers have more knowledge about composition of e-cigarettes $\left(\chi^{2}=7.966, s s=2, p=0.019\right)$ and more of them tried e-cigarettes than non-smokers $\left(\chi^{2}=5.576, s s=1, p=0.018\right)$. Conclusion: Questions related to knowledge show a lack of knowledge of the general population about possible consequences of long-term use e-cigarettes that can be expected. Populations at risk of consuming are younger men, having residency in the city, high school graduates, smokers and former smokers, so public health programs should be created and implemented to that population in cooperation with the educational and health sector.
\end{abstract}

Keywords: smoking, e-cigarettes, harmful effects of smoking, knowledge

Copyright @ 2021 KBCSM, Zagreb

e-mail: alcoholism.kbcsm@gmail.com•www.http://apr.kbcsm.hr

\section{Correspodence to:}

Zrinka Puharić, PhD, Professor Assistant, MD

University of Applied Sciences Bjelovar

Trg E. Kvaternika 4, 43000 Bjelovar, Croatia

Phone: + 385917981653

E-mail: zpuharic@vub.hr

\section{Introduction}

E-cigarettes or electronic cigarettes are battery-powered handheld devices, which heat a liquid to deliver a vapour, which is then inhaled by the user, consist of a battery an 
atomiser and a cartridge containing the liquid [1]. The liquid contains propylene glycol or glycerol, nicotine and flavouring agents which are generated from the thermal degradation of the heated liquid called "vaping toxicants" $[2,3]$. Products marked „nicotine-free“ have been found to contain nicotine even in higher concentration than in tobacco smoke [4]. Recent studies show that e-cigarettes can be harmful to lung tissue by imposing oxidative stress and inflammatory responses. Long term exposure to flavouring chemicals may lead to lung injurious responses [5]. Nicotine itself is not a carcinogen but may function as a "tumour promoter" and seems to be involved in the biology of malignant diseases, and long-term use is expected to increase the risk of chronic obstructive pulmonary disease, lung cancer and cardiovascular disease as well as some other diseases [6,7]. There is a shortage of data on the long-term effects of their use on individual because it have been in widespread use from 2007 [8] so the lack of data on effects is a source of serious concerns [9].

The e-cigarette use is becoming an emerging phenomenon of increasing popularity among young people $[10,11]$. The use of ecigarettes has increased from 3\% in 2010, to 7 and 11\% in 2012 and 2013. Furthermore, the number of people who reported having tried e-cigarettes has increased from $9 \%$ in 2010 to $22 \%$ in 2012 and 35\% in 2013 [1].

E-cigarettes are promoting as safe alternatives to conventional cigarettes and safe products without policy competences [12]. Advertisements give messages that e-cigarettes are less harmful and can be used for smoking cessation [13]. In 2016, the European Union Tobacco Products Directive overridden EU member states current domestic arrangements and imposed a ban on e-cig- arettes advertising, promotion and sponsorship, according to restrictions for tobacco products [14,15]. European commission report states that $88 \%$ of people have never tried e-cigarette, that is mostly used by current cigarette smokers (24\%) and 67\% are using it on a daily basis [16]. Law regulation of manufacturing, ingredients, advertising and selling e-cigarettes in Croatia are the same as for regular cigarettes [17].

\section{Subjects and Methods}

Study included 531 subjects who volunteered to participate and was done using online anonymous questionnaire in 2017; the link to questionnaire was on social media on the University of Applied Sciences Official web site. To limit duplicate responses, one response per IP address was permitted. Specially designed questionnaire using internationally validated surveys; ,The young people in Scotland schools omnibus 2014: questions on e-cigarettes", "Monitoring the future-National survey results on drug results" and The European commission-Special Eurobarometer Report-Attitudes of Europeans towards tobacco and electronic cigarettes [16,18,19].

Sociodemographic data included sex, age, level of education; elementary school or less, completed secondary school, and completed college or university, living in an urban or rural area and socio-professional category. Smoking status was ascertained by asking respondents if they currently smoked, occasionally smoked, former smoked and never smoked. Use of e-cigarettes was measures in two items: (1) "Have you ever tried an e-cigarette?" (yes, no, wish to try, do not wish to try); (2) "Are you currently using an e-cigarette?" (yes, no); knowledge of ecigarettes was measures in nine items: (1)“ 
Have you ever heard of e-cigarettes?" (yes, no); (2)"Where did you hear of e-cigarettes for the first time? (television, internet, newspaper, friends); (3)"Estimate your knowledge of e-cigarettes (fair, medium, excellent) “; (4) "Do you know its ingredients?" (yes, no); (5) "Is e-cigarette bad for your health (less than regular cigarettes, not unhealthy, equally bad, worse than regular cigarettes)"; (6) "Do you think that e-cigarettes help with smoking cessation?" (yes, no); (7) "Do you think that ecigarettes cause cancer?” (yes, no); (8) „Can people of all ages use e-cigarettes?" (yes, its use is completely forbidden, it is forbidden for minors and pregnant women, I do not know); (9) "Is it allowed to use e-cigarettes in places where smoking cigarettes is forbidden?" (yes, no). The questionnaire took approximately $30 \mathrm{~min}$ to complete.

\section{Statistical analyses}

Descriptive and inferential statistics are used to analyse the data obtained by the survey. Categorical data are presented using absolute and relative frequencies, percentages and tables. The variance of the category variables was tested by $\chi^{2}$ (square quadrature test), all $\mathrm{p}$ values are two-sided and, if necessary, for non-proportional and small samples, exact representations with corresponding corrections are shown in order to predict and explain the binary (selected) categorical variables. The level of test significance was set at $\alpha=0.05$, which assumed a confidence interval of $95 \%$. Statistical analysis used statistical program SPSS (Inox 21.0, SPSS Inc., Chicago, IL, USA). The analysis presents the difference in the attitudes and knowledge of e-cigarettes of respondents by gender, age, place of living, education and smoking status.
The logistic regression was based on the place of residence, the smoking status (non-smokers and former smokers: smokers and occasional smokers) and the profession (health professions: other professions) on questions: "Harmfulness of e-cigarettes”, „Does the smoking of e-cigarettes reduce the number of daily dropped classic cigarettes?", "Is ecigarette bad for your health?”, "Does smoking e-cigarette help quit smoking?", "Can smoking e-cigarettes cause cancer?" "Can ecigarettes be used in places where smoking is prohibited?".

\section{Results}

\section{Sample characterization}

There were 379 (71.4\%) women and 152 $(28.6 \%)$ men in the study. More than half of participants $295(55.6 \%)$ were in the age group $18-30$ years of age, 158 people $(29.8 \%)$ were in the 31-40 age group, $52(9.8 \%)$ were 41-50 years of age, $17(3.2 \%)$ were $51-60$ years of age and $9(1.7 \%)$ participant were 61 and older. 199 people $(37.5 \%)$ live in rural area and 332 participants $(62.5 \%)$ live in the city. Almost half 241 (45.4\%) respondents were healthcare professionals. According to their education level, only $7(1.3 \%)$ people have only elementary school degree, 282(53.1\%) have graduated high school and 242(39.2\%) have college degree.

\section{Knowledge and attitudes about e-cigarettes}

Almost all participants 520 (97.9\%) have heard of e-cigarettes, mostly from friends $340(64.3 \%)$ and internet $120(22.7 \%)$. Of all 531 respondents, $31(5.8 \%)$ of them use e-cigarettes every day: 14 men (9.2\%) and 17 $(4.5 \%)$ women. Using an e-cigarette at least once in life was reported by 250 (66.0\%) par- 
ticipants, $81(53.3 \%)$ men and $169(44.6 \%)$ women. Based on cigarette smoking status, $231(43.5 \%)$ of subjects were current smokers, $183(34.5 \%)$ were non-smokers, 63 $(11.9 \%)$ were former smokers and 54 (10.2\%) were occasional smokers.

Few people $52(9.8 \%)$ rate their knowledge of e-cigarettes to be fair, 153 (28.8\%) of them would like to know more and 322 $(30.9 \%)$ report they know ingredients in ecigarettes. More than half of participants 322 $(60.6 \%)$ say that they know of someone who uses e-cigarettes. Similar number of people think that e-cigarettes are equally unhealthy as cigarettes $223(42 \%)$ and that are less dangerous that cigarettes 207 (39\%). More than half of them $274(51.6 \%)$ do not know whether e-cigarettes cause lung cancer. Most advertisements for e-cigarettes were seen on social media 148 (27.9\%). Concerning people's level of education, $222(42 \%)$ think that e-cigarettes are harmful for health, younger population more than older. Almost half of participants $222(42.0 \%)$ think that e-cigarettes are harmful for pregnant women in the same way as classic cigarettes [28]. Almost half of people $236(44.4 \%)$ think that e-cigarettes are forbidden to minors and pregnant women, and $369(69.5 \%)$ that it is allowed to use e-cigarettes in places where smoking cigarettes is forbidden.

\section{Differences according to sex}

Based on sex differences, more men use e-cigarettes than women $\left(\chi^{2}=4.406\right.$, ss $=1$, $\mathrm{p}=0.036$ ), more men report knowing e-cigarette ingredients than women $\left(\chi^{2}=8.573\right.$, $\mathrm{ss}=2, \mathrm{p}=0.014)$, more men think all people can use e-cigarettes, more men have seen advertisements for e-cigarettes in the last 30 days $\left(\chi^{2}=4.256\right.$, $\left.s \mathrm{~s}=1, \mathrm{p}=0.039\right)$ and more women think that minor and pregnant are not allowed to use e-cigarettes $\left(\chi^{2}=9.903\right.$, $\mathrm{ss}=3, \mathrm{p}=0.019$ ).

\section{Differences according to age}

There is significant differences $\left(\chi^{2}=7.763\right.$, $\mathrm{ss}=2, \mathrm{p}=0.021)$ in e-cigarettes use between younger and older participants, most users are among age group 18-30 years of age $(60.8 \%)$.

\section{Differences according to place of residence}

According to urban or rural place of living, people from rural places have seen much less advertisements for e-cigarettes $\left(\chi^{2}=4.545, \mathrm{ss}=1, \mathrm{p}=0.033\right)$, e-cigarettes for sale $\left(\chi^{2}=10.497, \mathrm{ss}=1, \mathrm{p}=0.001\right)$, and sponsored event $\left(\chi^{2}=4.836, \mathrm{ss}=1, \mathrm{p}=0.028\right)$.

\section{Differences according to level of education}

More high school degree participants than college degree participants who have never tried e-cigarettes want to try it $\left(\chi^{2}=9.750\right.$, $\mathrm{ss}=3, \mathrm{p}=0.020$ ), more people with lower education have tried e-cigarettes more than people with higher level of education $\left(\chi^{2}=9.750\right.$, $\mathrm{ss}=3, \mathrm{p}=0.020)$, more of them think that ecigarette do not cause cancer $\left(\chi^{2}=7.147, \mathrm{ss}=2\right.$, $\mathrm{p}=0.028)$ and more of them do not know if it is allowed to use e-cigarettes in places where smoking is forbidden $\left(\chi^{2}=10.618\right.$, $\mathrm{ss}=3, \mathrm{p}=0.0114$ ).

\section{Differences according to smoking status}

According to smoking status, more smokers and occasional smokers currently use ecigarettes $\left(\chi^{2}=5.576, \mathrm{ss}=1, \mathrm{p}=0.018\right)$. More current and occasional smokers have at least once tried e-cigarettes $\left(\chi^{2}=90.527\right.$, ss $=3$, $\mathrm{p}=0.000)$, and think to know a lot about ecigarettes. Non-smokers report they do not know much about e-cigarettes $\left(\chi^{2}=17.994\right.$, 
$\mathrm{ss}=2, \mathrm{p}=0.000)$, whereas more smokers want to know more about e-cigarettes $\left(\chi^{2}=16.100\right.$, $\mathrm{ss}=1, \mathrm{p}=0.000)$ and report knowing ingredients of e-cigarettes better $\left(\chi^{2}=7.966\right.$, ss $=2$, $\mathrm{p}=0.019)$. In last 30 days more smokers and occasional smokers saw advertisements for e-cigarettes $\left(\chi^{2}=5.760\right.$, ss $\left.=1, p=0.016\right)$, more often on tv and in newspapers $\left(\chi^{2}=7.331\right.$, $\mathrm{ss}=1, \quad \mathrm{p}=0.007), \quad$ e-cigarettes for sale $\left(\chi^{2}=10.930, \mathrm{ss}=1, \mathrm{p}=0.001\right)$ and sponsored events $\left(\chi^{2}=5.402\right.$, ss $\left.=1, \mathrm{p}=0.020\right)$.

\section{Logistic regression}

\section{Differences according to place of residence}

Residents from the city (place with more than 5000 people) have 9.907 more likely to considering that smoking of e-cigarettes reduce the number of daily dropped classic cigarettes than those who live in a population of less than 5000 people (Table 1).

\section{Differences according to smoking status}

Smokers or occasional smokers have 0.658 more likely to believe that e-cigarette is bad for health compared to those who are non-smokers or former smokers (Table 2).

\section{Differences according to professions}

Professional health care workers are 0.760 more likely to disagree that smoking e-cigarette help quit smoking compared to those who are not health care professionals (Table 3).

Table 1. Differences according to place of residence

\begin{tabular}{|c|c|c|c|c|c|c|}
\hline & B & S.E. & Wald & $\mathrm{df}$ & Sig. & $\operatorname{Exp}(B)$ \\
\hline Knowledge & -0.057 & 0.286 & 0,040 & 1 & 0.841 & 0.944 \\
\hline Harmfulness of e-cigarettes & 0.216 & 0.204 & 1.112 & 1 & 0.292 & 1.241 \\
\hline $\begin{array}{l}\text { Does the smoking of e-cigarettes } \\
\text { reduce the number of daily } \\
\text { dropped classic cigarettes? }\end{array}$ & 2.293 & 1.095 & 4.387 & 1 & 0.036 & 9.907 \\
\hline Is e-cigarette bad for your health? & 0.137 & 0.191 & 0.516 & 1 & 0.473 & 1.147 \\
\hline $\begin{array}{l}\text { Does smoking e-cigarettes help } \\
\text { quit smoking? }\end{array}$ & 0.060 & 0.127 & 0.219 & 1 & 0.640 & 1.062 \\
\hline $\begin{array}{l}\text { Does smoking e-cigarettes can } \\
\text { cause cancer? }\end{array}$ & 0.035 & 0.117 & 0.092 & 1 & 0.762 & 1.036 \\
\hline $\begin{array}{l}\text { Does smoking e-cigarettes can } \\
\text { cause cancer? }\end{array}$ & 0.034 & 0.123 & 0.077 & 1 & 0.781 & 1.035 \\
\hline Constant & -5.249 & 2.412 & 4.738 & 1 & 0.030 & 0.005 \\
\hline
\end{tabular}

B - coefficient for the constant; S.E. - standard error; Wald - Wald chi-square test; $\mathrm{df}$ - degrees of freedom: Sig. - statistical significance: $\operatorname{Exp}(B)$ - exponentiation of the B coefficient (odds ratio) 
Table 2. Differences according to smoking status

\begin{tabular}{|c|c|c|c|c|c|c|}
\hline & $\mathrm{B}$ & S.E. & Wald & df & Sig. & $\operatorname{Exp}(B)$ \\
\hline Knowledge & 0.222 & 0.310 & 0.510 & 1 & 0.475 & 1.248 \\
\hline Harmfulness of e-cigarettes & 0.343 & 0.222 & 2.384 & 1 & 0.123 & 1.409 \\
\hline $\begin{array}{l}\text { Does the smoking of e-ciga- } \\
\text { rettes reduce the number of daily } \\
\text { dropped classic cigarettes? }\end{array}$ & 1.149 & 0.809 & 2.017 & 1 & 0.156 & 3.154 \\
\hline Is e-cigarette bad for your health? & -0.418 & 0.202 & 4.297 & 1 & 0.038 & 0.658 \\
\hline $\begin{array}{l}\text { Does smoking e-cigarettes help } \\
\text { quit smoking? }\end{array}$ & 0.080 & 0.138 & 0.333 & 1 & 0.564 & 1.083 \\
\hline $\begin{array}{l}\text { Does smoking e-cigarettes can } \\
\text { cause cancer? }\end{array}$ & -0.214 & 0.126 & 2.877 & 1 & 0.090 & 0.807 \\
\hline $\begin{array}{l}\text { Does smoking e-cigarettes can } \\
\text { cause cancer? }\end{array}$ & -0.071 & 0.130 & 0.296 & 1 & 0.586 & 0.932 \\
\hline Constant & -1.597 & 1.920 & 0.691 & 1 & 0.406 & 0.203 \\
\hline
\end{tabular}

B - coefficient for the constant; S.E. - standard error; Wald - Wald chi-square test; df - degrees of freedom: Sig. - statistical significance: $\operatorname{Exp}(B)$ - exponentiation of the B coefficient (odds ratio)

Table 3. Differences according to professions

\begin{tabular}{|c|c|c|c|c|c|c|}
\hline & $\mathrm{B}$ & S.E. & Wald & df & Sig. & $\operatorname{Exp}(B)$ \\
\hline Knowledge & 0.097 & 0.283 & 0.117 & 1 & 0.733 & 1.101 \\
\hline Harmfulness of e-cigarettes & 0.188 & 0.200 & 0.880 & 1 & 0.348 & 1.207 \\
\hline $\begin{array}{l}\text { Does the smoking of e-ciga- } \\
\text { rettes reduce the number of daily } \\
\text { dropped classic cigarettes? }\end{array}$ & 1.702 & 1.096 & 2.412 & 1 & 0.120 & 5.483 \\
\hline Is e-cigarettes bad for your health? & 0.335 & 0.190 & 3.089 & 1 & 0.079 & 1.397 \\
\hline $\begin{array}{l}\text { Does smoking e-cigarettes help } \\
\text { quit smoking? }\end{array}$ & -0.275 & 0.130 & 4.474 & 1 & 0.034 & 0.760 \\
\hline $\begin{array}{l}\text { Does smoking e-cigarettes can } \\
\text { cause cancer? }\end{array}$ & 0.163 & 0.118 & 1.908 & 1 & .167 & 1.177 \\
\hline $\begin{array}{l}\text { Does smoking e-cigarettes can } \\
\text { cause cancer? }\end{array}$ & 0.100 & 0.121 & 0.679 & 1 & 0.410 & 1.105 \\
\hline Constant & -4.700 & 2.388 & 3.874 & 1 & 0.049 & 0.009 \\
\hline
\end{tabular}

B - coefficient for the constant; S.E. - standard error; Wald - Wald chi-square test; df - degrees of freedom: Sig. - statistical significance: $\operatorname{Exp}(B)$ - exponentiation of the B coefficient (odds ratio) 


\section{Discussion}

This is the one of first studies to explore knowledge, attitudes and use of e-cigarettes in adult population, and to examine differences according to sex, age, place of living, educational status and smoking status. The prevalence rate of current use of e-cigarettes is $(5.8 \%)$ of all respondents $-9.2 \%$ men and $4.5 \%$ women, which is similar to the rates from studies in Great Britain 3.5\% [20], United States 4-7\%, France 6\%, Australia 7\% [21,22] and Serbia 1.6-2.3\% [23] but more than relevant data for Croatia from Special Eurobarometer which is only 1\% [16].

The lifetime prevalence is $66.0 \%$ - men $53.3 \%$ and women $44.6 \%$ which is more than in Serbia 8.5 - 10.8\%, United States 13 - 15\%, Australia 20\%, France 25.7\%, Netherlands $40 \%$ and in previous research in Croatia $8 \%$ [20,22-24]. People from the youngest age group (18-30 years of age) are the ones who tried e-cigarettes the most $60.8 \%$, like in some other studies - 48.8\% [23]. Almost all (97.9\%) participants in our study have heard of e-cigarettes, similar to the American study (91.9\%) [25]. In regard to people's level of education, $42 \%$ think that e-cigarettes are harmful for health, more with secondary school degree than with college degree $(46.0 \%$ compared to $57.0 \%$ ), younger population more than older (55.2\% compared to $4.0 \%$ ), which is similar to European Commission Report and research in America (46\%) [16,26]. Almost half of participants $(42.0 \%)$ think that e-cigarettes are harmful for pregnant women in the same way as classic cigarettes, similar with research from America (51.0\%) [27].

We have found that more women have seen e-cigarettes adds in the last 12 month than men, which is different from the European Commission report with men see- ing more adds. Knowledge of e-cigarettes in general is pretty law, and considering how many people have at least tried using it, it is slowly becoming public health problem [28]. Although there is no long term safety data, we have also found that general knowledge of e-cigarettes, and knowledge of its health danger compared to conventional cigarettes is low even in health care workers which is of particular concern. Populations at risk of using e-cigarettes are younger men, people living in the city, people with high school degree, smokers and former smokers, so public health programmes should be created and implemented in cooperation with the education and health sector in schools. Especially worrying is the growing number of minors who are using e-cigarettes because it is cheaper than classic cigarettes and offer a whole range of flavours. World Health Organization has proposed to forbid e-cigarettes use for minors [29]. New meta analytical research suggests that e-cigarettes users have two times more chance to become classic cigarette smokers [30]. In Croatia, the new Law on the Restriction of Use of Tobacco and Related Products in Accordance with EU Regulations regulates the status of e-cigarettes, starting with the definition and concept of e-cigarettes, up to mandatory health warnings, ban on sale to minors and forbidden any kind of forms of advertising and publicity [17].

Limitations of the study are as follows: participants are divided by age into three age groups, which was done for easier comparison with other researches. The study provides information of the prevalence and knowledge of e-cigarettes in general population and among health workers as well, which is particularly worrisome. The knowledge is not sufficient and future public health actions 
should be done to increase the level of information on health risk and ingredients of e-cigarettes, especially among young because many e-cigarettes are sweet flavoured and have attractive packaging, which makes them especially attractive to children.

\section{Conclusion}

Results show that almost half of the respondents at least once had experience with electric cigarette with a focus on younger generations. The population sample surveyed

\section{References}

1. Goniewicz ML, Kuma T, Gawron M, Knysak J, Kosmider L. Nicotine levels in electronic cigarettes. Nicotine Tob Res. 2013;15:158-66.

2. Grana R, Benowitz N, Glantz SA. Background paper on e-cigarettes. [Internet] Center for Tobacco Control Research and Education, University of California. 2013. [Cited 23 ${ }^{\text {rd }}$ March 2019] Available from: http://escholarship.org/uc/ item/13p2b72n.

3. Lerner CA, Sundar IK, Yao H, Gerloff J, Ossip DJ, McIntosh S, et al. Vapors produced by electronic cigarettes and e-juices with flavoring induce toxicity, oxidative stress and inflammatory response in lung epithelial cells in lung epithelial cells in mouse lung. PloS One. 2015;10:E0116732.

4. Visser W, Geraets L, Klerx W, Hernandez L, Stephens E, Croes E, et al. The health risks of using e-cigarettes. [Internet] National Institute for Public Health and the Environment, Netherlands. 2015 [Cited 23 ${ }^{\text {rd }}$ March 2019] Available from: https:// www.rivm.nl/bibliotheek/rapporten/2015-0144. pdf.

5. Gerloff J, Sundar IK, Freter R, Sekera ER, Friedman AE, Robinson R, et al. Inflammatory response and barrier dysfunction by different e-cigarette flavoring chemicals identified by gas chromatogra- shows insufficient knowledge of the harmfulness of the electronic cigarette, thus opening up space for public health work to bothhealth workers and the media.

\section{Acknowledgements}

None.

\section{Conflicts of interest}

The authors declare that they have no conflict of interest.

phy-mass spectrometry in e-liquids and e-vapors on human lung epithelial cells and fibroblasts. Appl In Vitro Toxicol. 2017;3:28-40.

6. U.S. Department of Health and Human Services. The Health Consequences of Smoking: 50 Years of Progress. A Report of the Surgeon General. [Internet] Atlanta 2014 [Cited 23 ${ }^{\text {rd }}$ March, 2019]. Available from: https://www.hhs.gov/sites/default/files/consequences-smoking-exec-summary. pdf.

7. Britton J, Arnott D, McNeill A, Hopkinson N, Tobacco Advisory Group of the Royal College of Physicians. Nicotine without smokeputting electronic cigarettes in context. BMJ. 2016;27;353:i1745.

8. Hajek P, Etter JF, Benowitz N, Eissenberg T, McRobbie H. Electronic cigarettes: review of use, content, safety, effects on smokers and potential for harm and benefit. Addiction. 2014;109:1801-10.

9. Trtchounian A, Talbot P. Electronic nicotine delivery systems: is there a need for regulation? Tob Control. 2011;20:47-52.

10. Barrington-Trimis JL, Samet JM, McConnell R. Flavourings in electronic cigarettes: an unrecognized respiratory health hazard? Jama. 2014;312:249394.

11. McMillen RC, Gottlieb MA, Shaefer RM, Winickoff JP, Klein JD. Trends in electronic cigarette 
use among U.S. adults: use is increasing in both smokers and nonsmokers. Nicotine Tob Res. 2015;17:1195-202.

12. Grana R, Benowitz N, Glantz SA. E-cigarettes: a scientific review. Circulation. 2014;129:1972-86.

13. Ramamurthi D, Fadadu RP, Jackler RK. Electronic cigarette marketers manipulate antitobacco advertisements to promote vaping. Tob Control. 2016;25:720-2.

14. Directive 2014/40/EU of the European Parliament and of the Council of 3 April 2014 on the approximation of the laws, regulations and administrative provisions of the Member States concerning the manufacture, presentation and sale of tobacco and related products and repealing Directive 2001/37/EC [Internet]. EUR-lex. 2014 [Cited 23 ${ }^{\text {rd }}$ March 2019]. Available from: https://eur-lex.europa.eu/legal-content/EN/TXT/?uri=OJ\%3AJ OL_2014_127_R_0001.

15. O'Loughlin J, Wellman RJ, Potvin L. Whiter the ecigarette? Int J Public Health. 2016;61:147-8.

16. Special Eurobarometer 458 Report-2017: Attitudes of Europeans towards tobacco and electronic cigarettes [Internet] 2019 [Cited 23 ${ }^{\text {rd }}$ March 2019] Available from: https://ec.europa.eu/commfrontoffice/publicopinion/[./79002.

17. Croatian Parliament. Act on Restrictions on the Use of Tobacco and Related Products. Narodne novine. 2017;45:114.

18. The Scottish government. Young people and ecigarettes in Scotland: A survey of secondary school pupils [Internet] 2014. [Cited 23 ${ }^{\text {rd }}$ March 2019]. Available from: http://www.gov.scot/Resource/0048/00486068.pdf.

19. Johnston LD, O'Malley PM, Miech RA, Bachman JG, Schulenberg JE. Monitoring the future national survey results on drug use, 1975-2015: overview, key findings on adolescent drug use. [Internet] Ann Arbor: Institute for Social Research, The University of Michigan. 2016 [Cited $23^{\text {rd }}$ March 2019]. Available from: https://eric. ed.gov/?id=ED578539.

20. Office for National Statistics. Adult smoking habits in Great Britain 2014. [Internet] 2014 [Cited 23 ${ }^{\text {rd }}$ March 2019] Available from: https://www. ons.gov.uk/releases/opinionsandlifestylesurveyadultsmokinghabitsingreatbritain 2014.
21. Hummel K, Hoving C, Nagelhout GE, de Vries $\mathrm{H}$, van den Putte B, Candel MJ, et al. Prevalence and reasons for use of electronic cigarettes among smokers: findings from the International Tobacco Control (ITC) Netherlands Survey. Int J Drug Policy. 2015;26:601-8.

22. Andler R, Guignard R, Wilquin JL, Beck F, Richard JB, Nguyen-Thanh V. Electronic cigarette use in France in 2014. Int J Pub Health. 2016;61:15965.

23. Kilibarda B, Mravcik V, Martens MS. E-cigarette use among Serbian adults: prevalence and user characteristics. Int J Pub Health. 2016;61:167-75.

24. McMillen RC, Gottlieb MA, Shaefer RM, Winickoff JP, Klein JD. Trends in electronic cigarette use among U.S. adults: use is increasing in both smokers and nonsmokers nicotine \& tobacco research. Nicotine Tob Res. 2015;17:1195-202.

25. Harrell MB, Weaver SR, Loukas A, Creamer M, Marti CN, Jackson CD, et al. Flavored e-cigarette use: characterizing youth, young adult, and adult users. Prev Med Rep. 2016;11:33-40.

26. Pericot-Valverde I, Gaalema DE, Priest JS, Higgins ST. E-cigarette awareness, perceived harmfulness, and ever use among U.S. adults. Prev Med. 2017;104:92-9.

27. Nguyen KH, Tong VT, Marynak KL, King BA. US adults' perceptions of the harmful effects during pregnancy of using electronic vapor products versus smoking cigarettes, Styles Survey, 2015. Prev Chronic Dis. 2016;22;13:E175.

28. Jankowski M, Brozek G, Lawson J, Skoczynski S, Zejda J. E-smoking: emerging public health problem? Int J Occup Med Environ Health. 2017;30:329-44.

29. World Health Organization Framework Convention on Tobacco Control. Conference of the parties to the WHO framework convention on tobacco control, sixth session [Internet] Geneva. 2014 [Cited 23 $3^{\text {td }}$ March 2019]. Available from: https:// apps.who.int/gb/fctc/PDF/cop6/FCTC_COP6_ VR_230115.pdf.

30. Zhong J, Cao S, Gong W, Fei F, Wang M. Electronic cigarettes use and intention to cigarette smoking among never-smoking adolescents and young adults: A meta-analysis. Int J Environ Res Public Health. 2016;13:465-74. 


\section{Znanje, stavovi i uporaba e-cigareta}

Sažetak - Cilj: Istražiti znanje, stavove i uporabu e-cigareta među stanovništvom u Hrvatskoj koristeći validirani on-line upitnik. Metode: Istraživanje je uključilo 531 ispitanika koji su dobrovoljno ispunili on-line anonimni validirani upitnik 2017. godine; poveznica na upitnik stavljena je na društvene mreže Veleučilišta u Bjelovaru. Za ograničavanje dupliciranih odgovora dopušten je jedan odgovor po IP adresi. Posebno dizajnirani upitnik načinjen je od međunarodno validiranih anketa: "The young people in Scotland schools omnibus 2014: questions on e-cigarettes", "Monitoring the future-National survey results on drug results" $i$ The European commission-Special Eurobarometer Report-Attitudes of Europeans towards tobacco and electronic cigarettes. Rezultati: U istraživanju je sudjelovalo $379(71,4 \%)$ žena i $152(28,6 \%)$ muškaraca. Gotovo svi $(97,9 \%)$ sudionici čuli su za pojam e-cigareta. Stopa prevalencije trenutne uporabe e-cigareta iznosi (5,8\%) svih ispitanika- 9,2\% muškaraca i 4,5\% žena. Muškarci znaju više o e-cigaretama $\left(\chi^{2}=8,573, s s=2, p=0,014\right)$, i koriste je češće od žena $\left(\chi^{2}=4,406\right.$, ss $\left.=1, p=0,036\right)$. Najveći broj korisnika je u dobnoj skupini od 18-30 godina, a najveći broj ispitanika koji vide oglase za e-cigarete, vidi ih na društvenim mrežama. Osobe nižeg obrazovanja probale su e-cigarete više od osoba s višim stupnjem obrazovanja $\left(\chi^{2}=9,750, s s=3, p=0,020\right)$. Pušači cigareta imaju više znanja o sastavu ecigareta $\left(\chi^{2}=7,966, s s=2, p=0,019\right)$, a više njih je probalo e-cigarete od nepušača $\left(\chi^{2}=5,576\right.$, $s s=1, p=0,018)$. Zaključak: Dio upitnika vezan uz znanje ispitanika pokazuje nedostatak znanja opće populacije o mogućim posljedicama dugotrajne uporabe e-cigareta. Ispitanici pod rizikom za konzumiranje e-cigareta su srednjoškolci, mlađi muškarci koji imaju prebivalište u gradu-urbanoj sredini, pušači i bivši pušači, tako da bi javnozdravstveni preventivni programi trebali biti kreirani i provedeni u toj populaciji u suradnji obrazovnog i zdravstvenog sektora.

Ključne riječi: korištenje e-cigarete, štetni učinci pušenja, znanje 